\title{
The Voyages of Captain Cook: A Bicentennial Exhibit
}

Twice in the 1760 's occurred a rare astronomical event which has been observed only five times in history and which will not occur at all in the twentieth century. This is the passage of the planet Venus across the face of the Sun. Until recent years the observation of this transit of Venus was important as furnishing a method of determining the fundamental astronomical unit, namely the Earth's mean distance from the Sun.

With the development of radar reflection techniques and the use of artificial satellites in solar orbit, it appears unlikely that the transits of the twenty-first century will be observed for this purpose. But it is not at all surprising that in the eighteenth century, as in the nineteenth, governments and scientific societies made careful plans to observe the transits of Venus from widely scattered points around the world. At least 151 observers at 77 stations observed the transit which occurred on June 3rd, 1769. ${ }^{1}$ It was this transit which occasioned the expeditions of Peter Simon Pallas to Siberia, of the Viennese Jesuit, Father Maximilian Hell, to Lapland, and of Captain Cook to Tahiti.

In June of 1766 the Royal Society of London began making plans for its observation of the forthcoming transit. Two of the observers selected by the Society were Charles Mason and Jeremiah Dixon, who had recently returned from the North American colonies, where they had surveyed the disputed boundary between Maryland and Pennsylvania, their "Mason and Dixon line" eventually becoming known as the division between the slave states and the free states. Mason was to go to County Donegal in northwest Ireland for his observations of the transit,

\footnotetext{
${ }^{1}$ Harry Woolf, The Transits of Venus: A Study of Eighteenth-Century Science (Princeton, 1959), p. 189.
} 
and Dixon to the island of Hammerfest, off the Norwegian coast. William Wales, who was later to teach mathematics at Christ's Hospital (where the pupils during his time included Samuel Taylor Coleridge, Charles Lamb, and Leigh Hunt), was to make his observations at Hudson's Bay; and the Society recommended that Alexander Dalrymple, a Fellow of the Society and an assiduous collector of charts and accounts of earlier voyages in the South Pacific, be sent to the island of Tahiti, which had recently been discovered by Captain Wallis in the Dolphin.

Dalrymple $e^{2}$ was a foremost proponent of the theory that an enormous land mass-the vaguely located Terra Australis Incognita of certain old charts-was yet to be discovered in the South Sea. According to this theory, propounded by Mercator and others, such a continent must exist in the south in order to balance the known continents of the north. But Dalrymple was not destined to discover such a continent, nor even to sail to Tahiti. He insisted that he would make the voyage only if he were put in command of the expedition, and this the Lords of the Admiralty refused to do on the ground that only an officer of the King's Navy should command a King's ship. Command of the expedition to Tahiti was given to a 39-year-old warrant officer named James Cook.

Cook had come to the favorable attention of the Admiralty through his superb work as a marine surveyor in North America. In addition to preparing detailed charts of the St. Lawrence River, he had during the past few years charted the coasts and principal harbors of Nova Scotia, Labrador, and Newfoundland. ${ }^{3}$ His observation of a solar eclipse in 1766, for the purpose of determining the longitude of Newfoundland, had been communicated to the Royal Society and published in its Transactions, and so he was not unknown to that scientific organization. Upon the rejection of the Society's first nominee, Dalrymple, James Cook, and Charles Green, a sometime assistant to the Astronomer Royal, were accepted as the Society's official observers, at Tahiti, of the forthcoming transit of Venus. Cook was promoted to lieu-

2 For a survey of Dalrymple's career and his relations with Cook, see Francis J. Bayldon, "Alexander Dalrymple. The Man Who Wished to Command the "Endeavour," Royal Australian Historical Society Journal and Proceedings, XIII, part 1 (1927), pp. 41-59.

${ }^{3}$ Cook's early work as a marine surveyor is bibliographed by R. A. Skelton and R. V. Tooley, "The Marine Surveys of James Cook in North America, 17581768," Map Collectors' Series, Vol. 4, no. 37 (1967). A facsimile edition of Cook's charts of Newfoundland has been published under the title James Cook, Surveyor of Newfoundland (San Francisco, 1965). 
tenant and in May of 1768 took command of his designated ship, the bark Endeavour, a converted coal-carrier of 366/2 tons.

Among his crew of seventy or so were five men who had served under him in Newfoundland, two men, John Gore and Charles Clerke, who had sailed round the world with Commodore Byron, and four (including Gore) who had been with the Dolphin in her recent circumnavigation. There were also thirteen marines and an apparently satisfactory cook who had lost his right hand. To crowd the accommodations to the utmost, Lieutenant Cook was advised that he was also to receive on board for the voyage a certain Joseph Banks and his party of eight.

Joseph Banks in 1768 was a remarkable young man of 25. Wealthy and insatiably inquisitive, he had a passion for botany which he shared with such older friends as Thomas Pennant, Gilbert White, and Daines Barrington. He was a correspondent of the great Swedish naturalist Linnaeus and a fishing companion of the first Lord of the Admiralty, the fourth Earl of Sandwich. He was later to become an adviser to King George III and to serve as president of the Royal Society for the unprecedented term of forty-two years. ${ }^{4}$

In Banks's entourage, along with two colored servants and two footmen from his country estate, were two artists and two naturalists. These included the very capable Daniel Solander, who had studied under Linnaeus and was later to become Keeper of the Natural History Department of the British Museum. Dr. Solander was to do most of the work of identifying, classifying, and naming the many new plants and animals that were discovered on the voyage. The most active of the artists was Sydney Parkinson, a young man of 23 who had previously exhibited flower paintings at the Society of Arts exhibitions in 1765 and 1766. During the voyage of the Endeavour he was to make more than 900 pencil sketches and water-color drawings of plants, birds, reptiles, fishes, and invertebrates, some of them of exquisite workmanship. ${ }^{5}$

\section{FIRST VOYAGE, 1768-1771}

Leaving Plymouth Harbour on August 26, 1768, the Endeavour stopped at Madeira to take on fresh water, a large supply of onions,

${ }^{4}$ His career is interestingly surveyed by Hector C. Cameron in Sir Joseph Banks, K.B., P.R.S., The Autocrat of the Philosophers (London, 1952).

${ }^{5}$ For a brief note on Parkinson's work, see F. C. Sawyer, "Some Natural History Drawings Made During Captain Cook's First Voyage Round the World," Journal of the Society for the Bibliography of Natural History, II, part 6 (October, 1950), pp. 190-193. 
and some 3,000 gallons of wine, and then sailed for South America. Toward the middle of November the ship was off the coast of Brazil, but much to the annoyance of Cook and his men they were refused permission by the Portuguese governor to disembark at Rio de Janeiro. Nonetheless they were able to purchase fresh fruit, meat, and vegetables, and while they lay at anchor Joseph Banks managed to slip ashore to botanize, Sydney Parkinson made twenty-two drawings of Brazilian fishes, and Cook drew a plan of the harbor. Christmas Day and New Year's came and went as they sailed southward, and in midJanuary they reached the eastern tip of Tierra del Fuego. In this unlikely spot (not to be botanized again till 1832, when Charles Darwin touched there in the Beagle) Banks, Solander, and a party went ashore and were caught overnight in a midsummer snowstorm. By morning, Banks's two Negro servants had frozen to death.

The passage around Cape Horn was remarkably smooth and in early April they reached Tahiti in good time to set up an observatory and tents and surround the spot with an earthenwork enclosure which they named Fort Venus. Despite this precaution and the presence of sentries, the light-fingered natives made off with the astronomical quadrant, but the instrument was recovered by Banks and repaired by the astronomer Green. June 3, 1769, was a bright and cloudless day at $\mathrm{Ta}-$ hiti, and the transit of Venus was independently observed by Cook, Green, and Solander. ${ }^{6}$ A three-month stay at this beautiful island gave Cook time to chart the coasts in detail and overhaul the ship while Banks collected birds and plants and made shrewd inquiries into the customs of the friendly natives. Two marines who tried to desert were brought back on board, a native priest named Tupia and his servantboy Tayeto were embarked, and on July 13th the Endeavour sailed westward to the neighboring islands of Huahine, Raiatea, and Bora Bora, which Cook surveyed and plotted on his charts.

Cook's instructions ${ }^{7}$ now required him to plunge southward 1500 miles to search for the mythical southern continent, which he was to chart and take possession of "in the name of the King of Great Britain." Should he fail to find such a continent, he was to sail westward to the land (New Zealand) which the Dutch navigator Abel Tasman had

6 "Every wished-for favourable circumstance attended the whole of that day, without one single impediment, excepting the heat, which was intolerable," Cook reported. "The thermometer which hung by the clock and was exposed to the sun as we were, was at one time as high as $119^{\circ}$." For Cook's report to the Royal Society on November 21, 1771, see Philosophical Transactions of the Royal Society, LXI (1771), pp. 397-436.

7 Cook's secret instructions were first printed in the Publications of the Navy Records Society, LXIII (1928), pp. 343ff. 
touched upon in 1642. On European charts, New Zealand was only a line which might possibly, it was thought, be the western edge of the great unknown continent. For over six weeks the Endeavour sailed to the south with no sign of the continent and then, with increasingly bad weather, turned westward toward New Zealand. Land was sighted on October 6, and Banks optimistically recorded that "all hands seem to agree that this is certainly the Continent we are in search of." The natives proved exceedingly hostile, but Tupia the Polynesian found that he could understand the language and make himself understood. ${ }^{8}$

Ten days were spent at Mercury Bay, where Charles Green observed a transit of Mercury, and the charting of the coast continued as Cook rounded the northern tip of New Zealand, fixed the position of Cape Maria van Diemen despite hurricanes and high seas, and in mid-January, 1770, put into Queen Charlotte's Sound to repair the ship. Here the natives were friendly, though from the presence of human bones near their campfires it was clear that they were cannibals. The naturalists saw none of the flightless birds of New Zealand, such as the kiwi, but Banks did hear the bell-birds and noted that "their voices were certainly the most melodious wild music I have ever heard, almost imitating small bells but with the most tuneable silver sound imaginable."

Having made a circuit of the northern island of New Zealand, Cook next sailed round the southern island, "to the total demolition of our aerial fabric called continent." In something over six months he circumnavigated both islands and charted them with such precision that his map of New Zealand has been called one of the major achievements of the eighteenth century. ${ }^{9}$

Having carried out his instructions, Cook decided, in council with his officers, to return to England by way of the East Indies. A return in high latitudes by way of Cape Horn would have permitted him to dispel the continental theory conclusively, since a large area of the South Pacific between $40^{\circ}$ and $60^{\circ} \mathrm{S}$. remained untraversed. Cook himself favored this Horn route, but the southern winter was approaching, and so on the first of April, 1770, the Endeavour left New Zealand and sailed westward. Cook's intention was to reach the unexplored eastern coast of Australia and follow it northward to New Guinea.

\footnotetext{
${ }^{8}$ Cook's first landing in New Zealand is recounted in detail by W. L. Williams, "On the Visit of Captain Cook to Poverty Bay and Tolaga Bay," Transactions and Proceedings of the New Zealand Institute, XXI (1888), pp. 389-397. See also J. A. Mackay, Historic Poverty Bay, 2nd ed. (Gisborne, N.Z., 1966), pp. 16-62.

${ }^{9}$ It is so characterized by J. C. Beaglehole, The Exploration of the Pacific, 3rd ed. (London, 1966), p. 244.
} 
On April 19 the coast of Australia was sighted, and ten days later a landing was made to take on fresh water. The exotic birds, wild flowers and gum trees were a delight to the botanists, and the abundance of large sting-rays in the bay at first impelled Cook to call this spot Stingray Harbour, a name he later changed to Botany Bay. (Botany Bay was later to become the site of the first British colony in the Pacific.) So numerous were the botanical acquisitions that the artist Sydney Parkinson was overwhelmed with work, although within fourteen days he made ninety-four sketches. Pelicans nearly five feet high were seen farther north, and in a mangrove swamp Banks found a species of green ants. Sailing near the coast, charting as he went, Cook unawares approached the Great Barrier Reef, and on a calm moonlit night, though soundings were continually being made, the Endeavour struck and grounded on the coral rocks.

Hoping to get his ship off at the next high tide, Cook jettisoned some forty or fifty tons of ballast and supplies, but the mid-morning tide was insufficient, and the leaks increased. Three pumps were manned, "at which every man on board assisted, the Captain, Mr. Banks, and all the officers, not excepted." With great good luck the sea remained calm and at high tide the next night, after twenty-three hours on the rocks, the ship floated free. A narrow river some thirty miles distant was found where the ship could be beached and repaired.

Seven weeks at the Endeavour River allowed Banks and Solander time to hunt and botanize and to attempt some contact with the natives. One of the men reported seeing a winged animal "about the size of, and much like, a one gallon cagg" (probably a flying fox) and John Gore became the first Englishman to shoot a kangaroo. The natives were a shy, naked, chocolate-brown race whose language differed from the Polynesian and Maori tongues. On August 6 the Endeavour was able to put to sea, though not before the natives, angry because they were not allowed to carry off a turtle from aboard the ship, had set fire to the grass surrounding Cook's campsite.

With difficulty Cook maneuvered his ship through the reef to the open sea, but this course proved even more dangerous than the treacherous navigation closer in, for the trade wind and the tide drove the ship toward huge breakers smashing against the rocks. Providentially, at the moment of greatest peril, an opening in the reef appeared, and the Endeavour hurried through and once again sailed along the coast inside the Great Barrier Reef. Two weeks of cautious sailing brought the ship to the Torres Strait, and Cook was able to confirm the existence of a sea passage between Australia and New Guinea. He had 
charted, during the past four months, nearly 2,000 miles of the hithertounknown coast of Eastern Australia.

Sailing again in known waters, the Endeavour, early in October, reached Batavia in Java. Here the ship was repaired by skillful Dutch shipwrights. Hitherto the men had been in good health, thanks to Cook's insistence on cleanliness and his unremitting attention to proper diet, and no one on his ship had succumbed to scurvy. But Batavia at that time was a pestilential port, and before the Endeavour could leave in late December, seven of her people had died, including the two Polynesians, Tupia and Tayeto, and many others were ill from malaria or dysentery. Before the ship reached the Cape of Good Hope in March, twenty-two more had died, among them the astronomer Charles Green and the artist Sydney Parkinson. After a voyage of nearly three years, Cook brought the Endeavour back to England and anchored in the Downs on July 13, 1771.

Upon the recommendation of David Garrick, Dr. Charles Burney, and perhaps other friends of Lord Sandwich, a writer named John Hawkesworth ${ }^{10}$ was chosen to edit the official account of Cook's first voyage. Hawkesworth was an early associate of Dr. Samuel Johnson and a writer of essays, reviews, poems, and oratorios. His scientific qualifications for this particular undertaking were meager, but he produced a readable work by conflating or dovetailing the separate journals kept by Cook and Banks. The work was eagerly awaited and appeared in 1773 as volumes two and three of a three-volume set entitled An Account of the Voyages undertaken by the Order of His Present Majesty for making Discoveries in the Southern Hemisphere, and successively performed by Commodore Byron, Captain Wallis, Captain Carteret, and Captain Cook, in the Dolphin, the Swallow, and the Endeavour: drawn up from the Journals which were kept by the several Commanders, and from the Papers of Joseph Banks, Esq. . . Illustrated with Cuts, and a great Variety of Charts and Maps relative to Countries now first discovered, or hitherto but imperfectly known.

These volumes were widely read, but Hawkesworth became the target of severe criticism, chiefly because he included descriptions of some of the more erotic native customs and because he did not attribute some of the lucky escapes of the voyagers to the particular interposition of Providence. The $£ 6000$ which he received for his editorial

${ }^{10}$ As yet no book-length study of Hawkesworth has been published, though a step in this direction has been made in Robert E. Gallagher's unpublished Northwestern University doctoral dissertation, John Hawkesworth: A Study Toward a Literary Biography (1957). 
work was perhaps small recompense for the ignominy which unfairly overtook him. Hawkesworth's alleged suicide is unproved, but undoubtedly his reputation was in eclipse after the publication of his book of voyages. "The severe reception it encountered, the suspicion of infidelity set on foot, and, above all, the strange fact of a lax magazine culling from it all the warmest passages to make a new art of love, preyed on his spirits, and drove him also to suicide."11

For 120 years it was through Hawkesworth's compilation that Cook's first voyage was known to the public. Not until 1893 did an edition of Cook's original journal appear. In that year Captain (later Admiral) W. J. L. Wharton, Hydrographer of the Admiralty, published an edition based upon a manuscript copy of Cook's journal now owned by the Mitchell Library, Sydney ${ }^{12}$ No copy of the journal in Cook's own handwriting was then known to exist, but in 1923 such a holograph journal was sold at auction and is now in the possession of the Commonwealth National Library, Canberra. It is this manuscript which furnished the basis of the now-standard text, edited with full apparatus by Professor J. C. Beaglehole and published in 1955 for the Hakluyt Society. ${ }^{13}$

There was no separate publication of Joseph Banks's journal until 1896, when Sir Joseph Dalton Hooker, eminent botanist, explorer, and lifelong friend of Charles Darwin, published a ruthlessly abridged version $^{14}$ based on a transcript of a nineteenth-century copy, Banks's original manuscript journal being then in private hands and unavailable. In 1958 the New Zealand pages of Banks's journal, edited from an eighteenth-century transcript now in the Alexander Turnbull Library, Wellington, were separately published, ${ }^{15}$ and finally in 1962 appeared a splendid two-volume edition of the entire journal, ${ }^{16}$ printed from Banks's original manuscript in the Mitchell Library, Sydney, and embellished with many of Sydney Parkinson's botanical drawings, some of which are reproduced in color.

Hawkesworth's compilation had included (without credit) engravings of some of Sydney Parkinson's drawings, and Parkinson's brother

11 Percy Fitzgerald, The Life of David Garrick, rev. ed. (London, 1899), p. 196.

12 W. J. L. Wharton, ed., Captain Cook's Journal during his First Voyage Round the World made in H. M. Bark "Endeavour" 1768-71 . . . (London, 1893).

${ }^{13} \mathrm{~J}$. C. Beaglehole, ed., The Journals of Captain James Cook on His Voyages of Discovery, Vol. 1: The Voyage of the Endeavour 1768-71 (Cambridge, 1955).

${ }_{14}$ Joseph D. Hooker, ed., Journal of the Right Hon. Sir Joseph Banks, Bart., K.B., P.R.S., during Captain Cook's First Voyage in H.M.S. Endeavour in 176871... . (London, 1896).

15 William P. Morrell, ed., Sir Joseph Banks in New Zealand (Wellington, 1958).

$16 \mathrm{~J}$. C. Beaglehole, ed., The Endeavour Journal of Joseph Banks 1768-1771, 2 vols. (Sydney, 1962). 
Stansfield was able to include some two dozen drawings in the edition of Sydney Parkinson's journal which appeared in 1773 under the title A Journal of a Voyage to the South Seas, in his Majesty's Ship, the Endeavour. . . ., but most of the Parkinson drawings were owned by Joseph Banks. Banks apparently planned to publish these in a sumptuous folio work with a text by Daniel Solander. Copperplate engravings of several hundred of the botanical and zoological drawings were actually prepared, and Daniel Solander's careful descriptions ${ }^{17}$ were largely completed, but following Solander's death in 1782 Banks lost interest in the projected work and it has never been published. In the Botanical Department of the British Museum (Natural History) at South Kensington repose hundreds of Parkinson's original drawings, the engraved plates and proof impressions, together with Solander's voluminous notes. Solander had hoped to publish a survey of natural history "comparable to that of Linné's Systema Naturae, but on an even more extensive and accurate scale than Gmelin's edition as well as more replete with personal knowledge."18 But today Solander is remembered, if he is remembered at all, as the inventor of the Solander case, a type of box sometimes used to protect rare books, which he devised to hold his notes.

(to be continued)

\footnotetext{
17 One scientist who has examined them reports that "Solander's descriptions are monuments of exactitude and have never been excelled." Tom Iredale, "Solander as an Ornithologist," The Ibis, I, tenth series (1913), pp. 134-135.

${ }^{18}$ Tom Iredale, "Solander as a Conchologist," Proceedings of the Malacological Society of London, XII (1916), p. 86.
} 

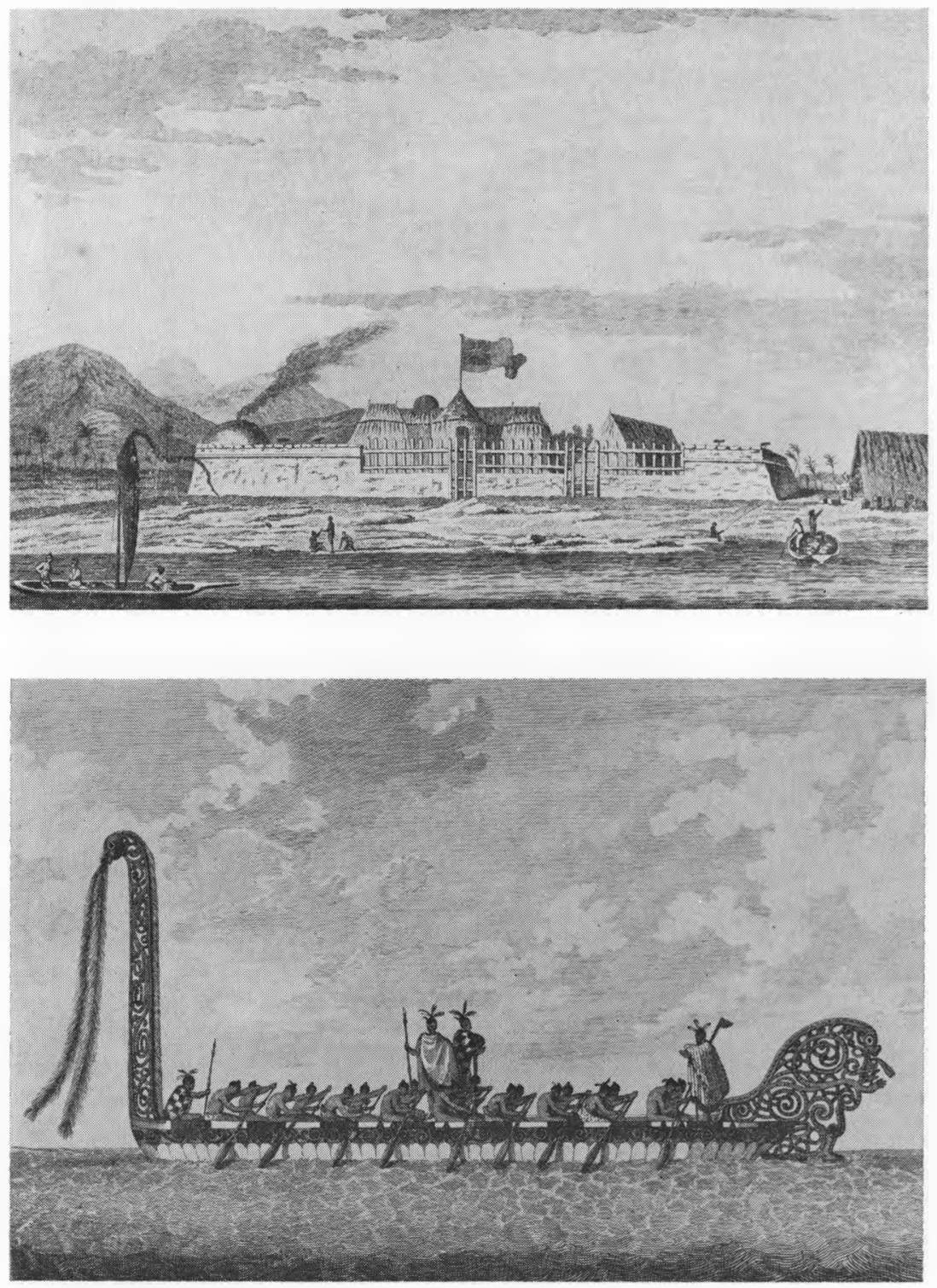

Two drawings by Sydney Parkinson, reproduced from the Library's first edition of Parkinson's A Journal of a Voyage to the South Seas, in His Majesty's Ship, the Endeavour, 1773. Above: "Venus Fort, Erected by the Endeavour's People, to secure themselves during the Observation of the Transit of Venus, at Otaheite." Below: "A War Canoe, of New Zealand." 

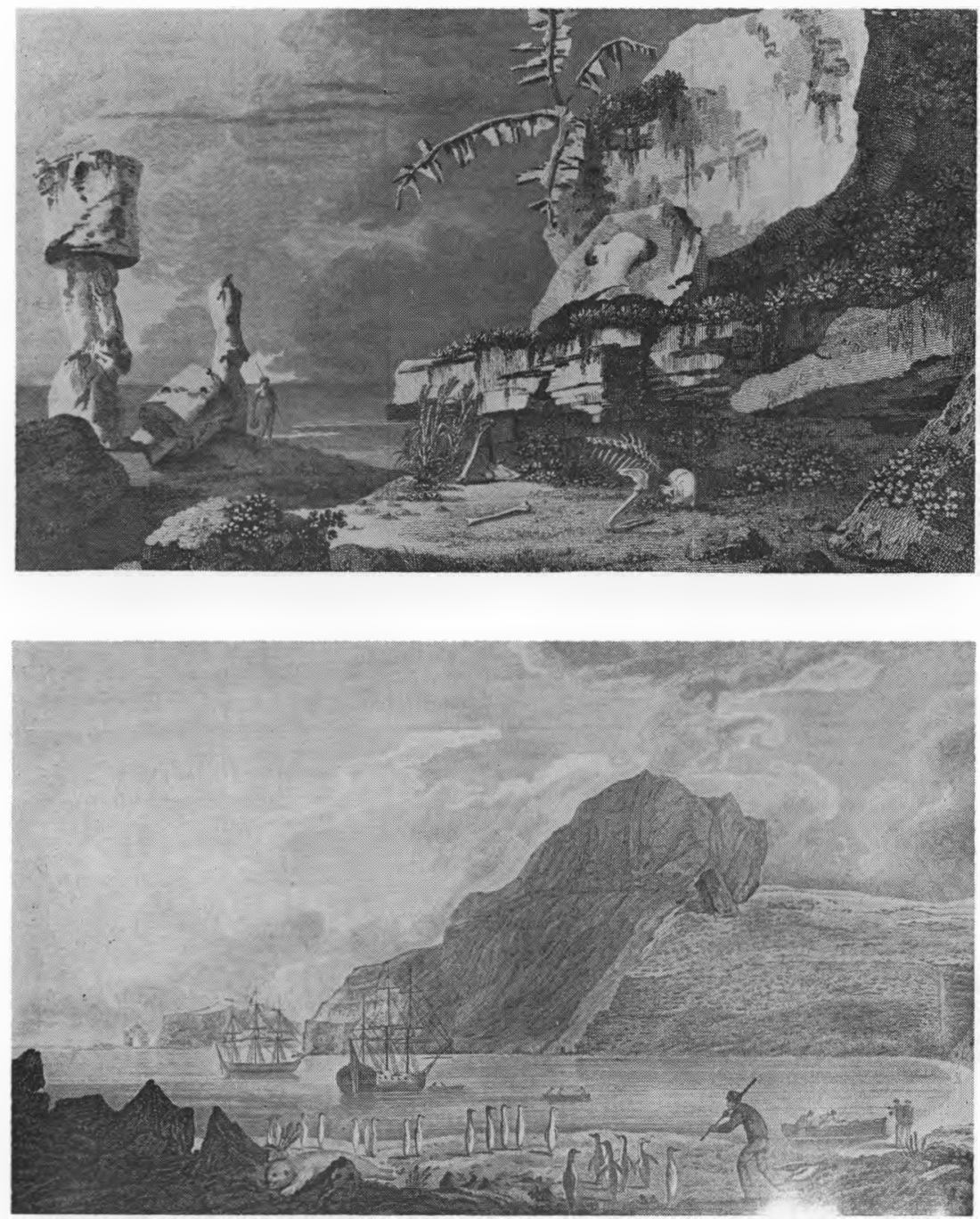

Above: Engraving of a scene on Easter Island, from a drawing by William Hodges, artist on Cook's second voyage. Below: "A View of Christmas Harbour, in Kerguelen's Land" from a drawing by John Webber, artist on Cook's third voyage. 